\title{
Diversity of Crops and Cropping Systems in Jessore Region
}

\author{
M M R Dewan ${ }^{1 *}$, M Harun Ar Rashid ${ }^{2}$, M Nasim³ and S M Shahidullah ${ }^{3}$
}

\begin{abstract}
Thorough understanding and a reliable database on existing cropping patterns, cropping intensity and crop diversity of a particular area are needed for guiding policy makers, researchers, extensionists and development workers for the planning of future research and development. During 2016 a study was accomplished over all 34 upazilas of Jessore region using pre-tested semi-structured questionnaire with a view to document the existing cropping patterns, cropping intensity and crop diversity in the region. The most dominant cropping pattern Boro-Fallow-T. Aman occupied $32.28 \%$ of net cropped area (NCA) of the region with its distribution in all upazilas. The second largest area, 5.29\% of NCA, was covered by single Boro, which was spread over 24 upazilas. A total of 176 cropping patterns were identified in the whole region under the current investigation. The highest number of cropping patterns was identified 58 in Kushtia sadar upazila and the lowest was 11 in Damurhuda upazila of Chuadanga district. The lowest crop diversity index (CDI) was reported 0.852 in Narail sadar upazila followed by 0.863 in Jessore sadar upazila. The highest value of CDI was observed 0.981 in Daulatpur followed by 0.978 in Bheramara upazila of Kushtia district. The range of cropping intensity values was recorded 175-286\%. The maximum value was for Sreepur of Magura district and minimum for Abhaynagar of Jessore district. As a whole the CDI of Jessore region was calculated 0.955 and the average cropping intensity at regional level was $229 \%$.
\end{abstract}

Key words: Cropping pattern, diversity index, favourable environment and non-rice cereal

\section{INTRODUCTION}

Cropping system is the crop production activity of a farm, which includes all cropping patterns grown on the farm resources, other household enterprises and the physical, biological, technological and socioeconomic factors or environments. A cropping pattern is the yearly sequence, temporal and partial arrangement of crops in a given land area. It is dependent on physical, historical, social, institutional and economic factors as well as government policies (Agrawal and Kassam, 1976). The cropping pattern and the changes therein depend on a large number of factors like climate, soil type, rainfall, agricultural technology, availability of irrigation facilities and other inputs, marketing and transport facilities and growth of agroindustries (Neena, 1998; Gadge, 2003).
The Jessore region includes the western part of the Ganges river floodplain which is predominantly highland and medium highland and it consists of 34 upazilas under seven districts. General soil types predominantly include calcareous dark grey floodplain soils and calcareous brown floodplain soils. Organic matter content in the brown ridge soils is low but higher in the dark grey soils. Soils are slightly alkaline in reaction. General fertility level is low. This region is suitable for agricultural crop production especially in cereals and vegetables. The cropping intensity is much higher than the other region of the country. The whole area holds comparatively dry weather than theother parts of the country. Low water holding capacity is an overall limitation for modern Boro rice cultivation in the region. Water stagnation is also a problem in some specific locations.

${ }^{1}$ BRRI RS Kushtia; ${ }^{2}$ BRRI RS Rajshahi; ${ }^{3}$ Rice Farming Systems Division, BRRI, Gazipur; *Corresponding author's E-mail: dewanbrri@yahoo.com 
The overall agricultural development in Bangladesh conceals considerable regional differences because of farming practices, techniques, availability of irrigation facilities, attitude of the farmer etc in different parts of the country. The differences in agricultural productivity among the regions to some natural phenomena, such as, rainfall, temperature, humidity and some other agro-ecological features which are relatively less favourable in the lagging regions. Jessore region plays a vital role of Agriculture in Bangladesh. The region produces a variety of crops year-round.

The yields of cereal crops are tending to stagnation, even in favourable environments. Moreover, cultivable land area is decreasing day by day in the country. To increase the system productivity of the total environment it needs to bring diversity in enterprises for better utilization of limited resources. Diversified cropping pattern may be an option for the farmers as a coping strategy against risks (Mandal and Bezbaruah, 2013). Typology of different cropping systems is the base for the managers of these systems to intensify production (Shriar, 2000). There is a strong need for judicious and appropriate use of limited resources in case of intervention selection that does not lead to increased mal adaption or inequity in the society over long term. Existing trends of available agricultural lands is most essential requirement for any land use planning related to farming and food security in a sustainable manner. Therefore, an increased understanding of arable land use based on the cropping system is essential for the appropriate intervention in sustainable way. In these context, existing cropping patterns along with their diversity of such complex agricultural region are very crucial for risk minimization and overall productivity improvement. The present study was designed with the following specific objectives to:

- Understand the existing cropping patterns scenario in Jessore region

- Visualize the existing land use pattern at upazila and regional level

- Determine the crop diversity and cropping intensity at upazila, district and regional level.

\section{METHODOLOGY}

Thirty-four upazilas of Jessore, Jhenaidaha, Magura, Narail, Kushtia, Meherpur and Chuadanga districts under Jessore agricultural region were the locale of this study. Data were collected using double stage procedure. At initial stage, data were collected through pretested semi-structured questionnaire from 34 pre-assigned Sub-Assistant Agriculture Officers (SAAO) of each upazila during January 2016 at upazila level. SAAOs were purposively preselected by Agriculture Extension Officers (AEO), Additional Agriculture Officer (AAO) and Upazila Agriculture Officer (UAO) or altogether. Prior to data collection, the pretested questionnaire was explained along with proper guidelines to the AEOs or UAOs or both and handed over to them at each Deputy Director's office of Department of Agricultural Extension (DAE) during monthly meeting for the sake of accurate data collection. The filled questionnaires were collected by the scientists of RFS Division, checked and analyzed to find the inconsistencies of the supplied data before validation workshop. All the inconsistencies among the information were documented. The collected data along with documented inconsistencies were discussed in district level workshop for necessary correction and validation. Second stage of data collection was day-long data validation workshop at district level. The workshop dates were 14 March for Narail and Magura; 15 March for Jhenaidaha; 12 April for Jessore; 13 April for Kushtia and 28 April 2016 for Chuadanga and Meherpur. Four field-workers i.e. one SAPPO and three SAAOs experienced and engaged in cropbased data documentation, all officers from all upazilas viz UAOs, AEOs, AAEOs, DD (DAE), DD (Horticulture), DD of Seed Certification Agency, DTO and ADDs, one representative from Agricultural Training Institute (ATI) and scientists of BRRI regional station, Kushtia and Satkhira participated in the data validation workshop. The number of participants of validation workshop ranged from 26 to 73 in each district. All the participants were divided into three to four groups for data validation. Each group was facilitated by two RFSD 
scientists to finalize and validate the data and authenticated data were captured. Crop diversity index was calculated by using the following equation described by Kshirsagar et al. (1997).

$$
C D I_{i}=1-\sum_{j=o}^{n}\left(\frac{a_{i j}}{A_{i}}\right)^{2}
$$

Where, $\mathrm{CDI}_{\mathrm{i}}=$ Crop Diversity Index

$a_{i j}=$ Area planted to the $j^{\text {th }}$ crop in the $i^{\text {th }}$ location

$A_{i}=$ Total area planted under all crops

The index is zero for a land area growing only one crop. It approaches unity as the level of diversity increases. Compilation and processing of collected data were done using Micro Soft Excel programme. Descriptive statistics were used to facilitate the presentation of the findings.

\section{RESULTS AND DISCUSSION}

\section{Land use}

Table 1 presents the status of agricultural land utilization. The net cropped area of the Jessore region is 736,920 ha. Crops occupied the particular land for round the year were considered under annual crops. The major annual crops reported in the region were sugarcane, banana, papaya, betel leaf, ginger and turmeric. The annual crops area in different upazilas ranged from 100 to 2,330 ha. The annual crops area accounted only $4.14 \%$ of the net cropped area (NCA) in the region. At a glance the region possesses $6 \%$ single cropped area (SCA), 52\% double cropped area (DCA), $37 \%$ triple cropped area (TCA). The quadruple cropped area also exists as a very negligible portion $(0.63 \%)$. The SCA was dominant in Abhaynagar and had the major share of NCA in Keshabpur of Jessore and Narail sadar upazila followed by corresponding double cropped area (DCA). Most of the upazilas were dominated by DCA. The exceptions are Manirampur of Jessore district; Mirpur, Khoksa and Bheramara of Kushtia district; Shailkupa of Jhenaidaha district and Jibannagar of Chuadanga district where triple cropped area was the dominating ones (Table 1). The area that could not be defined under SCA, DCA, TCA or QCA was considered as others whose coverage is less than $1 \%$ of the NCA.

\section{Cropping patterns of Jessore}

In total 176 cropping patterns were observed in Jessore region of which nine cropping patterns with exclusive rice crop covers about $46 \%$ of the NCA. There were 47 cropping patterns with exclusive non-rice crop covering over $12 \%$ of the NCA. Rest of the NCA i.e. around $42 \%$ area is covered by 120 rice - non rice cropping patterns (Appendix 1).

\section{Rice and non-rice crops at a glance}

Table 2 presents nine cropping patterns where rice is the only crop round the year. It comprises about $46 \%$ of the NCA in the region. Among them single rice, double rice and triple riceareas represent over $5 \%$, about $36 \%$ and about $3 \%$ respectively. It reflects the unparallel dominance of rice in the cropping systems in jessore region. In case of individual pattern Boro-Fallow-T. Aman has the highest coverage $(32.28 \%)$ and was recorded in all 34 upazilas. The second dominant pattern single Boro area occupied $5.29 \%$ of NCA which was reported in 24 upazilas. Boro-Aus-T. Aman covered 2.76\% area with its existence in only 15 upazilas.

In the current investigation, 47 cropping patterns were identified that was free from rice. Among these 47 patterns, first 32 have been arranged in descending order in Table 3. The rest 15 patterns with negligible area coverage (Table 9) are arranged with other patterns of different categories. Aggregate of the 47 patterns have had over $12 \%$ of NCA. In critical comparison, it is clear that exclusive rice area is about four folds of exclusive non-rice area. In Jessore region crop diversity is much wider than that of other regions like Sylhet and Chittagong where exclusive rice area covers 37 folds and 23 folds respectively, of exclusive non-rice area (Muttaleb et al., 2017; Shahidullah et al., 2017). Appropriate cropping patterns may facilitate maximum possible land utilization as well as efficient use of other scarce resources 
Table 1. Land use of different upazilas in Jessore region (area in hectare), 2014-15.

\begin{tabular}{|c|c|c|c|c|c|c|c|c|c|c|}
\hline & Upazila & $\begin{array}{l}\text { Area of } \\
\text { upazila }\end{array}$ & $\begin{array}{c}\text { Annual } \\
\text { crop }\end{array}$ & SCA & DCA & TCA & QCA & Other & NCA & C.I. (\%) \\
\hline 01 & Jessore sadar & 43298 & 460 & 80 & 19790 & 10520 & 100 & 160 & 31110 & 233 \\
\hline 02 & Keshabpur & 25903 & 990 & 6000 & 8300 & 4560 & 0 & 190 & 20040 & 188 \\
\hline 03 & Manirampur & 44499 & 570 & 2500 & 15800 & 16200 & 1000 & 100 & 36170 & 242 \\
\hline 04 & Abhaynagar & 24719 & 590 & 8100 & 4010 & 3200 & 200 & 190 & 16290 & 168 \\
\hline 05 & Jhikargachha & 30809 & 320 & 100 & 14450 & 8550 & 0 & 150 & 23570 & 235 \\
\hline 06 & Sarsha & 33642 & 180 & 700 & 14650 & 8900 & 1200 & 150 & 25780 & 241 \\
\hline 07 & Bagherpara & 27096 & 350 & 660 & 10320 & 7410 & 80 & 130 & 18950 & 235 \\
\hline 08 & Chougachha & 26919 & 560 & 1300 & 10420 & 5320 & 300 & 160 & 18060 & 223 \\
\hline 09 & Kushtia sadar & 31857 & 1890 & 230 & 11640 & 8760 & 400 & 170 & 23090 & 232 \\
\hline 10 & Mirpur & 30454 & 690 & 1110 & 5120 & 16350 & 200 & 120 & 23590 & 264 \\
\hline 11 & Kumarkhali & 25837 & 700 & 710 & 8850 & 6660 & 0 & 180 & 17100 & 231 \\
\hline 12 & Khoksa & 10376 & 1020 & 0 & 2530 & 4030 & 0 & 140 & 7720 & 240 \\
\hline 13 & Daulatpur & 48228 & 1330 & 750 & 17590 & 14400 & 0 & 160 & 34230 & 236 \\
\hline 14 & Bheramara & 15370 & 1650 & 460 & 2530 & 4210 & 100 & 100 & 9050 & 226 \\
\hline 15 & Magura sadar & 40130 & 590 & 680 & 11680 & 15480 & 0 & 160 & 28590 & 250 \\
\hline 16 & Sreepur & 17719 & 720 & 170 & 2200 & 10730 & 0 & 200 & 14020 & 271 \\
\hline 17 & Shalikha & 22864 & 120 & 0 & 9000 & 8120 & 0 & 130 & 17370 & 246 \\
\hline 18 & Mohammadpur & 22930 & 230 & 1730 & 5310 & 8400 & 0 & 160 & 15830 & 241 \\
\hline 19 & Meherpur sadar & 26152 & 1060 & 40 & 10300 & 9910 & 0 & 150 & 21460 & 241 \\
\hline 20 & Gangni & 33932 & 620 & 0 & 12000 & 11090 & 0 & 110 & 23820 & 244 \\
\hline 21 & Mujibnagar & 11354 & 660 & 600 & 4600 & 2830 & 0 & 120 & 8810 & 218 \\
\hline 22 & Narail sadar & 37226 & 600 & 5000 & 17410 & 5090 & 0 & 100 & 28200 & 198 \\
\hline 23 & Lohagara & 28485 & 370 & 1450 & 13020 & 7090 & 0 & 140 & 22070 & 224 \\
\hline 24 & Kalia & 30177 & 700 & 0 & 19900 & 2930 & 0 & 170 & 23700 & 209 \\
\hline 25 & Jhenaidaha sadar & 46775 & 1620 & 350 & 15500 & 9200 & 0 & 150 & 26820 & 227 \\
\hline 26 & Shailkupa & 37345 & 1980 & 3000 & 8900 & 15380 & 700 & 120 & 30080 & 239 \\
\hline 27 & Kotchandpur & 16095 & 1090 & 1040 & 7550 & 2780 & 0 & 130 & 12590 & 205 \\
\hline 28 & Moheshpur & 41903 & 1310 & 1970 & 21360 & 9020 & 0 & 150 & 33810 & 217 \\
\hline 29 & Harinakundu & 22723 & 2330 & 0 & 8920 & 3340 & 0 & 140 & 14730 & 207 \\
\hline 30 & Kaliganj & 31114 & 1820 & 430 & 11360 & 8060 & 0 & 150 & 21820 & 227 \\
\hline 31 & Chuadnga sadar & 29855 & 990 & 20 & 15130 & 4230 & 0 & 120 & 20490 & 216 \\
\hline 32 & Alamdanga & 36528 & 1670 & 2200 & 20000 & 5450 & 350 & 100 & 29770 & 208 \\
\hline 33 & Jibannagar & 19933 & 100 & 0 & 6500 & 8450 & 0 & 150 & 15200 & 255 \\
\hline \multirow[t]{2}{*}{34} & Damurhuda & 30344 & 640 & 0 & 14250 & 7980 & 0 & 120 & 22990 & 232 \\
\hline & Jessore region & & 30520 & 41380 & 380890 & 274630 & 4630 & 4870 & 736920 & 229 \\
\hline
\end{tabular}

Table 2. Cropping patterns with exclusive rice in Jessore region, 2014-15.

\begin{tabular}{|c|c|c|c|c|}
\hline & Cropping pattern & Area (ha) & $\%$ of NCA & Frequency (no. of upazila) \\
\hline 01 & Boro-Fallow-T. Aman & 237850 & 32.28 & 34 \\
\hline 02 & Boro-Fallow-Fallow & 39010 & 5.29 & 24 \\
\hline 03 & Boro-Aus-T. Aman & 20350 & 2.76 & 15 \\
\hline 04 & Boro-Aus-Fallow & 17000 & 2.31 & 16 \\
\hline 05 & Boro-B.Aman & 8250 & 1.12 & 6 \\
\hline 06 & Fallow-B.Aus+B. Aman & 500 & 0.07 & 1 \\
\hline 07 & Fallow-Fallow-T. Aman & 300 & 0.04 & 1 \\
\hline 08 & Fallow-B.Aman & 180 & 0.02 & 3 \\
\hline \multirow[t]{2}{*}{09} & Fallow-Aus-Fallow & 70 & 0.01 & 1 \\
\hline & Total & 323510 & 43.90 & \\
\hline
\end{tabular}


Table 3. Cropping patterns with exclusive non-rice in Jessore region, 2014-15.

\begin{tabular}{|c|c|c|c|c|}
\hline & Cropping pattern & Area (ha) & $\%$ of NCA & Frequency (no. of upazila) \\
\hline 01 & Vegetab-Vegetab-Vegetab & 19170 & 2.60 & 25 \\
\hline 02 & Maize-Jute-Fallow & 9900 & 1.34 & 7 \\
\hline 03 & Wheat-Jute-Fallow & 7960 & 1.08 & 9 \\
\hline 04 & Lentil-Jute-Fallow & 7550 & 1.02 & 13 \\
\hline 05 & Grasspea-Jute-Fallow & 6140 & 0.83 & 6 \\
\hline 06 & Vegetab-Vegetab-Fallow & 4120 & 0.56 & 9 \\
\hline 07 & Wheat-Chilli-Fallow & 3350 & 0.45 & 4 \\
\hline 08 & Lentil-Vegetab-Vegetab & 2780 & 0.38 & 10 \\
\hline 09 & Wheat-Jute-Blackgram & 2750 & 0.37 & 4 \\
\hline 10 & Onion-Jute-Fallow & 2600 & 0.35 & 9 \\
\hline 11 & Onion-Vegtab-Vegetab & 2090 & 0.28 & 10 \\
\hline 12 & Mustard-Jute-Vegetab & 1900 & 0.26 & 5 \\
\hline 13 & Maize-Vegetab-Fallow & 1750 & 0.24 & 4 \\
\hline 14 & Vegetab-Jute-Fallow & 1730 & 0.23 & 5 \\
\hline 15 & Chilli-Vegetab-Fallow & 1330 & 0.18 & 13 \\
\hline 16 & Vegetab-Fallow-Blackgram & 1250 & 0.17 & 4 \\
\hline 17 & Wheat-Vegetab-Vegetab & 1240 & 0.17 & 6 \\
\hline 18 & Pea-Jute-Fallow & 1170 & 0.16 & 6 \\
\hline 19 & Wheat-Jute-Vegetab & 1100 & 0.15 & 3 \\
\hline 20 & Garlic-Jute-Fallow & 1040 & 0.14 & 5 \\
\hline 21 & Garlic-Vegetab-Vegetab & 850 & 0.12 & 8 \\
\hline 22 & Chilli-Fallow-Fallow & 840 & 0.12 & 6 \\
\hline 23 & Maize-Mungbean-Vegetab & 800 & 0.11 & 1 \\
\hline 24 & Pea-Vegetab-Fallow & 800 & 0.11 & 3 \\
\hline 25 & Vegetab-Jute-Vegetab & 800 & 0.11 & 1 \\
\hline 26 & Lentil-Sesame-Fallow & 770 & 0.11 & 3 \\
\hline 27 & Maize-Groundnut & 620 & 0.08 & 1 \\
\hline 28 & Potato-Sesame-Fallow & 540 & 0.07 & 2 \\
\hline 29 & Potato-Jute-Fallow & 530 & 0.07 & 4 \\
\hline 30 & Vegetab-Maize-Fallow & 510 & 0.07 & 2 \\
\hline 31 & Mustard-Jute-Fallow & 450 & 0.06 & 2 \\
\hline 32 & Coriander-Fallow-Fallow & 300 & 0.04 & 3 \\
\hline \multirow[t]{2}{*}{$33-47$} & Other 15 patterns (in Table 9) & 1410 & 0.19 & - \\
\hline & Total & 90140 & 12.23 & \\
\hline
\end{tabular}

in a sustainable manner. Diversified cropping pattern may be an option for the farmers as a coping strategy against risks (Mandal and Bezbaruah, 2013). Typology of different cropping systems is the base for the managers of these systems to intensify production (Shriar, 2000).

\section{Non-rice cereal crops}

Forty cropping patterns are holding different non-rice cereal crops (Table 4). Among them wheat, with the largest area, is leading 17 patterns cultivated on 59,920 hectares that is equivalent to $8.11 \%$ of NCA. Maize holds the second position in non-rice cereal crop cultivation in Jessore region. There are 24 cropping patterns for maize, which in-together occupy $7.27 \%$ of NCA. In the documentation of non-rice cereal cropping systems wheat reported widest spreading e.g. Wheat-Jute-T. Aman is distributed over 29 upazilas out of 34 . Overall, the aggregate area of the nonrice cereal cropping system stands for $15.41 \%$ of the NCA in Jessore region. In Bangladesh there is a vast market of maize seeds for feed industries. Loam and sandy-loam soil of the comparative dry area is very suitable for maize 
Table 4. Cropping patterns based on maize and wheat in Jessore region, 2014-15.

\begin{tabular}{|c|c|c|c|c|}
\hline & Cropping pattern & Area (ha) & $\%$ of NCA & Frequency (no. of upazila) \\
\hline 01 & Wheat-Jute-T. Aman & 30300 & 4.11 & 29 \\
\hline 02 & Maize-Aus-Fallow & 10850 & 1.47 & 6 \\
\hline 03 & Maize-Jute-Fallow & 9900 & 1.34 & 7 \\
\hline 04 & Maize-Fallow-T. Aman & 9000 & 1.22 & 7 \\
\hline 05 & Wheat-Jute-Fallow & 7960 & 1.08 & 9 \\
\hline 06 & Maize-Jute-T. Aman & 5580 & 0.76 & 9 \\
\hline 07 & Maize-Mungbean-T. Aman & 4900 & 0.66 & 3 \\
\hline 08 & Wheat-Sesame-T. Aman & 3750 & 0.51 & 9 \\
\hline 09 & Wheat-Chilli-Fallow & 3350 & 0.45 & 4 \\
\hline 10 & Maize-Aus-Vegetab & 3000 & 0.41 & 4 \\
\hline 11 & Wheat-Fallow-T. Aman & 2910 & 0.39 & 8 \\
\hline 12 & Wheat-Jute-Blackgram & 2750 & 0.37 & 4 \\
\hline 13 & Wheat-Aus-T. Aman & 2130 & 0.29 & 8 \\
\hline 14 & Wheat-Aus-Fallow & 1910 & 0.26 & 5 \\
\hline 15 & Maize-Vegetab-Fallow & 1750 & 0.24 & 4 \\
\hline 16 & Maize-Sesame-T. Aman & 1530 & 0.21 & 7 \\
\hline 17 & Maize-Vegetab-T. Aman & 1260 & 0.17 & 3 \\
\hline 18 & Wheat-Vegetab-Vegetab & 1240 & 0.17 & 6 \\
\hline 19 & Wheat-Jute-Vegetab & 1100 & 0.15 & 3 \\
\hline 20 & Mustard-Maize-T. Aman & 900 & 0.12 & 2 \\
\hline 21 & Vegetab-Maize-T. Aman & 880 & 0.12 & 1 \\
\hline 22 & Wheat-Mungbean-T. Aman & 810 & 0.11 & 6 \\
\hline 23 & Maize-Mungbean-Vegetab & 800 & 0.11 & 1 \\
\hline 24 & Wheat-Vegetab-T. Aman & 670 & 0.09 & 4 \\
\hline 25 & Maize-Groundnut & 620 & 0.08 & 1 \\
\hline 26 & Wheat-Aus-Cotton & 600 & 0.08 & 1 \\
\hline 27 & Maize-Aus-T. Aman & 580 & 0.08 & 3 \\
\hline 28 & Potato-Maize-T. Aman & 550 & 0.07 & 2 \\
\hline 29 & Vegetab-Maize-Fallow & 510 & 0.07 & 2 \\
\hline 30 & Wheat-Aus-Blackgram & 300 & 0.04 & 2 \\
\hline 31 & Maize-Sesame-Fallow & 280 & 0.04 & 2 \\
\hline 32 & Mustard-Maize-Jute & 200 & 0.03 & 1 \\
\hline 33 & Tobacco-Maize-T. Aman & 190 & 0.03 & 2 \\
\hline \multirow[t]{2}{*}{$34-40$} & Other seven patterns (in Table 9) & 480 & 0.07 & \\
\hline & Total area for wheat and maize & 113540 & 15.41 & \\
\hline
\end{tabular}

cultivation. Wheat cultivation with its better yield in this region is specially favoured by long winter season that is normally unavailable in southern parts of the country. Light textured soil with low water-holding capacity as well as less availability of irrigation water are driving forces that discourage the farmers for modern Boro cultivation. During the harvesting period of wheat the crop is privileged by clear sunshine and low humidity. All these are the factors this area is dominated by wheat-based cropping systems (FAO, 1988).

\section{Fibre crops}

Jute is the main fibre crop in Bangladesh. Once it is called Golden Fibre. Socially and economically jute is an important crop in the Jessore region. There are 41 cropping patterns were identified based on jute (Table 5). It is observed that the jute based cropping patterns covered $23.90 \%$ of NCA of the Jessore region. Among them Wheat-Jute-T. Aman cropping pattern absolutely occupies $4.11 \%$ of the NCA which is distributed over 29 upazilas out of 34 covering 30,300 hectares of land area. The 
second prevailing Lentil-Jute-T. Aman covers 29,650 hectare area which is $4.02 \%$ of the NCA. Tobacco-Jute-T. Aman stands in third position in terms of area coverage, however, it is narrowly distributed in only eight upazilas out of 34. Well-drained light-textured soil makes the friendly situation for early growth stages of jute. High temperature, high humidity, satisfactory rainfall are the pre-requisites for cultivation of the crop. Plenty of flood water is timely available in the region for jute retting. Clear sun-shine during the harvesting period is an extra facility for post-harvest management of fibre and stick. Now-a-days jute-stick also has a good market value with export potential. All these make a favourable package which encourages the farmers for extensive jute cultivation in the region (FAO, 1988).

\section{Tobacco in cropping systems}

Tobacco is the exceptional crop which is cultivated in Jessore region mainly in Kushtia district. Product of tobacco is harmful to the human. Table 6 presents nine cropping

Table 5. Jute-based cropping patterns in Jessore region, 2014-15.

\begin{tabular}{|c|c|c|c|c|}
\hline & Cropping pattern & Area (ha) & $\%$ of NCA & Frequency (no. of upazila) \\
\hline 01 & Wheat-Jute-T. Aman & 30300 & 4.11 & 29 \\
\hline 02 & Lentil-Jute-T. Aman & 29650 & 4.02 & 23 \\
\hline 03 & Tobacco-Jute-T. Aman & 12180 & 1.65 & 8 \\
\hline 04 & Onion-Jute-T. Aman & 10740 & 1.46 & 21 \\
\hline 05 & Mustard-Jute-T. Aman & 10710 & 1.45 & 15 \\
\hline 06 & Maize-Jute-Fallow & 9900 & 1.34 & 7 \\
\hline 07 & Wheat-Jute-Fallow & 7960 & 1.08 & 9 \\
\hline 08 & Lentil-Jute-Fallow & 7550 & 1.02 & 13 \\
\hline 09 & Boro-Jute-T. Aman & 6320 & 0.86 & 11 \\
\hline 10 & Boro-Jute-Fallow & 6250 & 0.85 & 7 \\
\hline 11 & Grasspea-Jute-Fallow & 6140 & 0.83 & 6 \\
\hline 12 & Maize-Jute-T. Aman & 5580 & 0.76 & 9 \\
\hline 13 & Tobacco-Jute-Fallow & 3950 & 0.54 & 6 \\
\hline 14 & Garlic-Jute-T. Aman & 3100 & 0.42 & 14 \\
\hline 15 & Wheat-Jute-Blackgram & 2750 & 0.37 & 4 \\
\hline 16 & Onion-Jute-Fallow & 2600 & 0.35 & 9 \\
\hline 17 & Mustard-Boro-Jute-T. Aman & 2500 & 0.34 & 5 \\
\hline 18 & Grasspea-Jute-T. Aman & 2150 & 0.29 & 10 \\
\hline 19 & Mustard-Jute-Vegetab & 1900 & 0.26 & 5 \\
\hline 20 & Vegetab-Jute-Fallow & 1730 & 0.23 & 5 \\
\hline 21 & Vegetab-Jute-T. Aman & 1310 & 0.18 & 4 \\
\hline 22 & Mustard-Boro-Jute & 1200 & 0.16 & 1 \\
\hline 23 & Pea-Jute-Fallow & 1170 & 0.16 & 6 \\
\hline 24 & Potato-Jute-T. Aman & 1150 & 0.16 & 9 \\
\hline 25 & Wheat-Jute-Vegetab & 1100 & 0.15 & 3 \\
\hline 26 & Garlic-Jute-Fallow & 1040 & 0.14 & 5 \\
\hline 27 & Coriander-Jute-T. Aman & 1010 & 0.14 & 8 \\
\hline 28 & Vegetab-Jute-Vegetab & 800 & 0.11 & 1 \\
\hline 29 & Chilli-Jute-T. Aman & 740 & 0.10 & 6 \\
\hline 30 & Potato-Jute-Fallow & 530 & 0.07 & 4 \\
\hline 31 & Mustard-Jute-Fallow & 450 & 0.06 & 2 \\
\hline 32 & Blackgram-Jute-T. Aman & 300 & 0.04 & 1 \\
\hline 33 & Potato-Boro-Jute & 250 & 0.03 & 1 \\
\hline 34 & Coriander-Jute-Fallow & 200 & 0.03 & 2 \\
\hline 35 & Mustard-Maize-Jute & 200 & 0.03 & 1 \\
\hline 36 & Potato-Boro-Jute-T. Aman & 200 & 0.03 & 1 \\
\hline \multirow[t]{2}{*}{$37-41$} & Other five patterns (in table 9) & 520 & 0.07 & - \\
\hline & Total area for jute & 176130 & 23.90 & \\
\hline
\end{tabular}


patterns that comprises $3.20 \%$ of the NCA in the region mainly of triple cropped areas. The pattern Tobacco-Jute-T. Aman has the highest coverage ( $1.65 \%$ of the NCA) and was recorded in eight upazilas out of 34 followed by Tobacco-Jute-Fallow. In consideration of human health and social impact the tobacco crop is discouraged on principle. However, people of the concerned area can not give up tobacco cultivation. Famers consider the crop as an insurance of his property. Industry personnel make assurance to purchase their products with high price. Moreover, they pay advance money as production cost. They supply all inputs and technologies for successful production of tobacco. These are privileges of farmers for tobacco cultivation.

\section{Pulse crops under the cropping systems}

Forty-four cropping patterns are holding different pulse crops (Table 7). Among them lentil is covering the largest area whereas chickpea in the smallest area. Twelve cropping patterns of lentil in-together cover $8.52 \%$ of NCA. Grasspea holds the second position in pulse crop cultivation in Jessore region. There are 11 cropping patterns for grasspea covering $2.11 \%$ NCA in the region. Top three patterns viz Grasspea-Jute-Fallow, Grasspea-B.Aman and Grasspea-Jute-T. Aman in-together occupy over $0.92 \%$ of NCA. Finally the aggregate area of the pulse cropping system stands for $12.02 \%$ of the NCA in Jessore region. In some specific area of Jessore region Boro cultivation faces some constraints such as scarcity of irrigation water, very light soil with low-water holding capacity. Moreover, high market price of pulse crops is driving force for ample cultivation of pulse crops. Among the Rabi crops stress- tolerant grasspea can easily be grown as relay system (FAO, 1988).

\section{Oil-seed crops}

Thirty-two cropping patterns have been arranged in descending order according to area coverage in Table 8. Mustard is the most important one among the oil-seed crops in Jessore region. There are 17 cropping patterns had been led by mustard alone which intogether covers 55,700 ha $(7.56 \%$ of NCA). The pattern Mustard-Boro-T. Aman has the highest coverage (3.07\% of the NCA) and was recorded in 21 upazilas out of 34 followed by Mustard-Jute-T. Aman (1.45\% of NCA).

\section{Sporadic and distinct cropping patterns}

There are some cropping patterns, which are extremely location-specific, however, with a large area coverage. These are MustardBoro-Jute (Table 8), Tobacco-Sesbania-T. Aman (Table 6) and Onion-Fallow-T. Aman (Appendix 1). The Mustard-Boro-Jute is grown on 1,200 haonly in Sarsha of Jessore district. Tobacco-Sesbania-T. Aman is cultivated on 1,600 ha only in Mirpur upazila of Kushtia district. Onion-Fallow-T. Aman is limited to two upazilas viz Bheramara (250 ha) and Kumarkhali (1,500 ha).

\section{Rare cropping patterns}

In the present investigation, 40 cropping patterns have been identified as rare cropping patterns with a negligible area coverage with seldom existence (Table 9). These are location specific system and are limited in one or two or in some cases three upazilas of the region. Total area coverage of the 40 patterns is is far below

Table 6. Tobacco based cropping patterns in Jessore region, 2014-15.

\begin{tabular}{rlrrc}
\hline Cropping pattern & Area (ha) & \% of NCA & Frequency (no. of upazila) \\
\hline 1 Tobacco-Jute-T. Aman & 12180 & 1.65 & 8 \\
2 & Tobacco-Jute-Fallow & 3950 & 0.54 & 6 \\
3 & Tobacco-Aus-T. Aman & 2950 & 0.40 & 3 \\
4 & Tobacco-Fallow-T. Aman & 1670 & 0.23 & 6 \\
5 & Tobacco-Sesbania-T. Aman & 1620 & 0.22 & 2 \\
6 & Tobacco-Aus-Fallow & 930 & 0.13 & 3 \\
$7-9$ & Other three patterns (in table 9) & 280 & 0.04 & \\
\hline Total tobacco & 23580 & 3.20 & \\
\hline
\end{tabular}


Table 7. Cropping patterns with pulse crops in Jessore region, 2014-15.

\begin{tabular}{|c|c|c|c|c|}
\hline & Cropping pattern & Area (ha) & $\%$ of NCA & Frequency (no. of upazila) \\
\hline 01 & Lentil-Jute-T. Aman & 29650 & 4.02 & 23 \\
\hline 02 & Lentil-Jute-Fallow & 7550 & 1.02 & 13 \\
\hline 03 & Lentil-Sesame-T. Aman & 6630 & 0.90 & 17 \\
\hline 04 & Grasspea-Jute-Fallow & 6140 & 0.83 & 6 \\
\hline 05 & Lentil-Mungbean-T. Aman & 5080 & 0.69 & 14 \\
\hline 06 & Lentil-Aus-T. Aman & 4800 & 0.65 & 5 \\
\hline 07 & Grasspea-B.Aman & 4450 & 0.60 & 5 \\
\hline 08 & Lentil-Aus-Fallow & 2950 & 0.40 & 4 \\
\hline 09 & Lentil-Vegetab-Vegetab & 2780 & 0.38 & 10 \\
\hline 10 & Wheat-Jute-Blackgram & 2750 & 0.37 & 4 \\
\hline 11 & Lentil-Vegetab-T. Aman & 2250 & 0.31 & 4 \\
\hline 12 & Grasspea-Jute-T. Aman & 2150 & 0.29 & 10 \\
\hline 13 & Vegetab-Fallow-Blackgram & 1250 & 0.17 & 4 \\
\hline 14 & Pea-Jute-Fallow & 1170 & 0.16 & 6 \\
\hline 15 & Grasspea-Fallow-T. Aman & 1100 & 0.15 & 9 \\
\hline 16 & Grasspea-Aus-T. Aman & 900 & 0.12 & 5 \\
\hline 17 & Pea-Aus-Vegetab & 900 & 0.12 & 4 \\
\hline 18 & Pea-Vegetab-Fallow & 800 & 0.11 & 3 \\
\hline 19 & Lentil-Sesame-Fallow & 770 & 0.10 & 3 \\
\hline 20 & Pea-Fallow-T. Aman & 740 & 0.10 & 6 \\
\hline 21 & Boro-Fallow-Blackgram & 530 & 0.07 & 3 \\
\hline 22 & Blackgram-Jute-T. Aman & 300 & 0.04 & 1 \\
\hline 23 & Wheat-Aus-Blackgram & 300 & 0.04 & 2 \\
\hline 24 & Pea-B.Aman & 280 & 0.04 & 3 \\
\hline 25 & Lentil-Fallow-T. Aman & 240 & 0.03 & 3 \\
\hline 26 & Grasspea-B.Aus+B.Aman & 200 & 0.03 & 1 \\
\hline 27 & Grasspea-Sesame-Fallow & 200 & 0.03 & 2 \\
\hline 28 & Onion-Aus-Blackgram & 200 & 0.03 & 1 \\
\hline \multirow[t]{2}{*}{$29-44$} & Other 16 patterns (in table 9) & 1500 & 0.20 & \\
\hline & Total area for pulse crops & 88560 & 12.02 & \\
\hline
\end{tabular}

$1 \%$ of NCA. Among these the highest area was allotted for Groundnut-Fallow-Fallow (190 ha) and it is recorded in Kumarkhali of Kushtia, Mohammadpur upazila of Magura district and of Meherpur sadar upazila. The smallest area was recorded for four cropping patterns whose coverage was 20 hectares for each (Table 9).

\section{Most dominant cropping pattern}

Boro-Fallow-T. Aman was the most dominant cropping pattern in Jessore region. It covers $32.28 \%$ of NCA in the region and is available in all 34 upazilas (Table 10). The highest area under this cropping pattern was recorded 17,000 ha in Jessore sadar upazila which represents $7.15 \%$ of the total Boro-Fallow-T. Aman area of the region. In consideration of individual upazila
Jhenaidaha sadar upazila stand on the $2^{\text {nd }}$ position for area coverage, however, this upazila has allocated biggest share i.e. 58\% of its NCA for this pattern alone. Bheramera upazila had a negligible area coverage for this pattern. In the country-wide data compilation it was observed that Boro-F-T. Aman was the most dominant cropping pattern in Bangladesh covering 2.31 million ha $(27 \%$ of NCA in the country) with its distribution in 426 upazilas of 63 districts (Nasim et al., 2017).

\section{Second dominant cropping pattern}

Single Boro cropping pattern holds the second largest area coverage 39,010 ha in Jessore region. This area is an equivalent to $5.29 \%$ of NCA in the region. This pattern Boro-Fallow- 
Table 8. Cropping patterns with oil-seed crops in Jessore region, 2014-15.

\begin{tabular}{|c|c|c|c|c|}
\hline & Cropping pattern & Area (ha) & $\%$ of NCA & Frequency (no. of upazila) \\
\hline 01 & Mustard-Boro-T. Aman & 22600 & 3.07 & 21 \\
\hline 02 & Mustard-Jute-T. Aman & 10710 & 1.45 & 15 \\
\hline 03 & Lentil-Sesame-T. Aman & 6630 & 0.90 & 17 \\
\hline 04 & Mustard-Boro-Aus & 5050 & 0.69 & 4 \\
\hline 05 & Wheat-Sesame-T. Aman & 3750 & 0.51 & 9 \\
\hline 06 & Mustard-Boro-Jute-T. Aman & 2500 & 0.34 & 5 \\
\hline 07 & Mustard-Mungbean-T. Aman & 2370 & 0.32 & 10 \\
\hline 08 & Mustard-Aus-T. Aman & 2220 & 0.30 & 6 \\
\hline 09 & Mustard-Sesame-T. Aman & 2060 & 0.28 & 6 \\
\hline 10 & Mustard-Jute-Vegetab & 1900 & 0.26 & 5 \\
\hline 11 & Mustard-Boro-Aus-T. Aman & 1650 & 0.22 & 6 \\
\hline 12 & Maize-Sesame-T. Aman & 1530 & 0.21 & 7 \\
\hline 13 & Mustard-Boro-Fallow & 1290 & 0.18 & 4 \\
\hline 14 & Mustard-Boro-Jute & 1200 & 0.16 & 1 \\
\hline 15 & Mustard-Maize-T. Aman & 900 & 0.12 & 2 \\
\hline 16 & Lentil-Sesame-Fallow & 770 & 0.10 & 3 \\
\hline 17 & Onion-Sesame-T. Aman & 650 & 0.09 & 2 \\
\hline 18 & Maize-Groundnut & 620 & 0.08 & 1 \\
\hline 19 & Potato-Sesame-T. Aman & 620 & 0.08 & 5 \\
\hline 20 & Potato-Sesame-Fallow & 540 & 0.07 & 2 \\
\hline 21 & Groundnut- Aus-T. Aman & 500 & 0.07 & 1 \\
\hline 22 & Mustard-Jute-Fallow & 450 & 0.06 & 2 \\
\hline 23 & Mustard-Fallow-T. Aman & 300 & 0.04 & 1 \\
\hline 24 & Maize-Sesame-Fallow & 280 & 0.04 & 2 \\
\hline 25 & Mustard-Aus-Fallow & 200 & 0.03 & 3 \\
\hline 26 & Grasspea-Sesame-Fallow & 200 & 0.03 & 2 \\
\hline 27 & Mustard-Maize-Jute & 200 & 0.03 & 1 \\
\hline $28-32$ & Other five patterns (in table 9) & 430 & 0.06 & \\
\hline & Total area for oil-seed crops & 72120 & 9.79 & \\
\hline
\end{tabular}

Fallow is distributed over only 24 upazilas (Table 11). Abhaynagar has an area of 7,800 ha for single Boro which stands for $19.99 \%$ of the total area under this pattern in the region. Jessore sadar had a negligible area coverage for this pattern. This pattern is frequent and concurrently experienced by early flash flood in April and cold injury at reproductive stage. Diversified cropping pattern may be resort for the farmer as a coping strategy with flood related risk (Mandal and Bezbaruah, 2013) but scope of diversification is limited due to environmental and climatic condition (FAO, 1988). In the country-wide data compilation it was observed that the single Boro was the $2^{\text {nd }}$ dominant cropping pattern in Bangladesh covering 1.14 million ha $(13 \%$ of NCA in the country) with its distribution in 342 upazilas of 59 districts (Nasim et al., 2017).

\section{Third dominant cropping pattern}

The third dominant cropping pattern in Jessore region is Wheat-Jute-T. Aman. It belongs to $4.11 \%$ of NCA of the region and spread out over 29 upazilas (Table 12). Shailkupa upazila of Jhenaidaha district hold the highest area $(3,500$ ha) which represents $11.55 \%$ of the total WheatJute-T. Aman area of the region. Sreepur stands in the third position, however, this upazila of Magura district has allocated the biggest share i.e. $21 \%$ surface of its NCA. In the countrywide compilation of data it was observed that Wheat-Jute-T. Aman was the $9^{\text {th }}$ dominant cropping pattern in Bangladesh covering 1.47 lac ha $(1.72 \%$ of NCA in the country) with its distribution in 216 upazilas of 43 districts (Nasim et al., 2017). 
Table 9. Rare cropping patterns covering non-significant area in Jessore region, 2014-15.

\begin{tabular}{|c|c|c|c|c|c|}
\hline & Cropping pattern & Area (ha) & $\%$ of NCA & Frequency & Upazila \\
\hline 01 & Groundnut-Fallow-Fallow & 190 & 0.03 & 3 & Kumarkhali+Md.pur+Meherpur \\
\hline 02 & Tobacco-Maize-T. Aman & 190 & 0.03 & 2 & Daulatpur+Mirpur \\
\hline 03 & Fallow-B.Aman & 180 & 0.02 & 3 & Kotchandpur+Kushtia+Magura \\
\hline 04 & Chilli-Jute-Fallow & 180 & 0.02 & 2 & Lohagara+Kalia \\
\hline 05 & Potato-Aus-Fallow & 180 & 0.02 & 2 & Harinakundu+Jessore \\
\hline 06 & Grasspea-Mungbean-T. Aman & 170 & 0.02 & 1 & Narail sadar \\
\hline 07 & Garlic-Aus-Fallow & 160 & 0.02 & 3 & Chougachha+Khoksa+Kumarkhali \\
\hline 08 & Potato-Boro-T. Aman & 150 & 0.02 & 3 & Jessore+Kaliganj+Moheshpur \\
\hline 09 & Grasspea-Fallow-Fallow & 150 & 0.02 & 1 & Magura sadar \\
\hline 10 & Vegetab-Fallow-Fallow & 150 & 0.02 & 1 & Kotchandpur \\
\hline 11 & Potato-Boro-Fallow & 140 & 0.02 & 2 & Chougachha+Kaliganj \\
\hline 12 & Fallow-Fallow-Blackgram & 130 & 0.02 & 1 & Bheramara \\
\hline 13 & Chickpea-Fallow-T. Aman & 110 & 0.01 & 3 & Bagherpara+Jessore+Kushtia \\
\hline 14 & Coriander-Vegetab-Fallow & 110 & 0.01 & 3 & Khoksa+Kumarkhali+Shalikha \\
\hline 15 & Chickpea-Jute-T. Aman & 100 & 0.01 & 3 & Jessore+Magura+Sreepur \\
\hline 16 & Coriander-Fallow-T. Aman & 100 & 0.01 & 3 & Jhikargachha+Kushtia+Mirpur \\
\hline 17 & Lentil-Mungbean-Jute-T. Aman & 100 & 0.01 & 1 & Manirampur \\
\hline 18 & Maize-Fallow-Blackgram & 100 & 0.01 & 1 & Chuadanga sadar \\
\hline 19 & Mungbean-Fallow-T. Aman & 100 & 0.01 & 1 & Jessore sadar \\
\hline 20 & Mungbean-Jute-Fallow & 100 & 0.01 & 1 & Daulatpur \\
\hline 21 & Mustard-M.bean-Aus-T. Aman & 100 & 0.01 & 1 & Manirampur \\
\hline 22 & Sesame-Fallow-T. Aman & 100 & 0.01 & 2 & Magura sadar+Kaliganj \\
\hline 23 & Wheat-Mungbean-Fallow & 100 & 0.01 & 1 & Jhikargachha \\
\hline 24 & Potato-Aus-T. Aman & 80 & 0.01 & 1 & Jessore sadar \\
\hline 25 & Potato+S.gourd-M.bean-T. Aman & 80 & 0.01 & 1 & Bagherpara \\
\hline 26 & Fallow-Aus-Fallow & 70 & 0.01 & 1 & Mohammadpur \\
\hline 27 & Grasspea-Boro-Fallow & 70 & 0.01 & 1 & Kumarkhali \\
\hline 28 & S.Potato-Fallow-Fallow & 60 & 0.01 & 3 & Moheshpur+Kumarkhali+Magura \\
\hline 29 & Garlic-Aus-T. Aman & 60 & 0.01 & 1 & Moheshpur \\
\hline 30 & Grasspea-Sesame-T. Aman & 50 & 0.01 & 1 & Kumarkhali \\
\hline 31 & Lentil-B.Aman & 50 & 0.01 & 1 & Kumarkhali \\
\hline 32 & Tobacco-Mungbean-T. Aman & 50 & 0.01 & 1 & Mirpur \\
\hline 33 & Garlic-Fallow-T. Aman & 40 & 0.01 & 1 & Bheramara \\
\hline 34 & S.Potato-Jute-Fallow & 40 & 0.01 & 1 & Daulatpur \\
\hline 35 & Tobacco-Mungbean-Vegetab & 40 & 0.01 & 1 & Bheramara \\
\hline 36 & Maize-Maize-T. Aman & 30 & 0.00 & 1 & Jessore sadar \\
\hline 37 & Onion-Maize-Fallow & 20 & 0.00 & 1 & Kumarkhali \\
\hline 38 & Potato-Sesame-Aus & 20 & 0.00 & 1 & Jessore sadar \\
\hline 39 & Wheat-Maize-Fallow & 20 & 0.00 & 1 & Kumarkhali \\
\hline \multirow[t]{2}{*}{40} & Wheat-Sesame-Fallow & 20 & 0.00 & 1 & Chuadanga sadar \\
\hline & Total & 3890 & 0.53 & - & \\
\hline
\end{tabular}


Table 10. Distribution of the most dominant Boro-Fallow-T. Aman cropping patterns in Jessore region, $2014-15$.

\begin{tabular}{|c|c|c|c|c|}
\hline & Upazila & Area (ha) & $\%$ of upazila NCA & $\%$ of the pattern in region \\
\hline 01 & Jessore sadar & 17000 & 55.46 & 7.15 \\
\hline 02 & Jhenaidaha sadar & 14500 & 57.54 & 6.10 \\
\hline 03 & Manirampur & 13500 & 37.92 & 5.68 \\
\hline 04 & Sarsha & 13000 & 50.78 & 5.47 \\
\hline 05 & Kalia & 12900 & 56.09 & 5.42 \\
\hline 06 & Moheshpur & 10700 & 32.92 & 4.50 \\
\hline 07 & Kaliganj & 10300 & 51.50 & 4.33 \\
\hline 08 & Bagherpara & 9800 & 52.69 & 4.12 \\
\hline 09 & Jhikargachha & 9800 & 42.15 & 4.12 \\
\hline 10 & Magura sadar & 9500 & 33.93 & 3.99 \\
\hline 11 & Narail sadar & 9200 & 33.33 & 3.87 \\
\hline 12 & Damurhuda & 8900 & 39.82 & 3.74 \\
\hline 13 & Shailkupa & 8900 & 31.67 & 3.74 \\
\hline 14 & Chougachha & 8300 & 47.43 & 3.49 \\
\hline 15 & Kushtia sadar & 8100 & 38.21 & 3.41 \\
\hline 16 & Alamdanga & 8000 & 39.80 & 3.36 \\
\hline 17 & Shalikha & 7800 & 45.22 & 3.28 \\
\hline 18 & Harinakundu & 6500 & 52.42 & 2.73 \\
\hline 19 & Jibannagar & 6500 & 43.05 & 2.73 \\
\hline 20 & Keshabpur & 5600 & 29.40 & 2.35 \\
\hline 21 & Chuadanga sadar & 5400 & 27.69 & 2.27 \\
\hline 22 & Meherpur sadar & 4500 & 22.06 & 1.89 \\
\hline 23 & Kotchandpur & 4000 & 34.78 & 1.68 \\
\hline 24 & Abhaynagar & 3700 & 23.57 & 1.56 \\
\hline 25 & Mirpur & 3500 & 15.28 & 1.47 \\
\hline 26 & Gangni & 3500 & 15.09 & 1.47 \\
\hline 27 & Kumarkhali & 3300 & 20.12 & 1.39 \\
\hline 28 & Lohagara & 2850 & 13.13 & 1.20 \\
\hline 29 & Mohammadpur & 2200 & 14.10 & 0.92 \\
\hline 30 & Mujibnagar & 1800 & 22.09 & 0.76 \\
\hline 31 & Daulatpur & 1600 & 4.86 & 0.67 \\
\hline 32 & Sreepur & 1300 & 9.77 & 0.55 \\
\hline 33 & Khoksa & 1200 & 17.91 & 0.50 \\
\hline \multirow[t]{2}{*}{34} & Bheramara & 200 & 2.70 & 0.08 \\
\hline & Jessore region & 237850 & 32.28 & 100.00 \\
\hline
\end{tabular}

\section{Fourth dominant cropping pattern}

Fourth dominant cropping pattern LentilJute-T. Aman has occupied 29,650 hectares representing $4.02 \%$ share of NCA in Jessore region (Table 13). This pattern is distributed over 23 upazilas where Magura sadar ranked in top position. This upazila has 4,400 ha area Lentil-Jute-T. Aman which is only $15.71 \%$ of upazila NCA. Mohammadpur upazila ranks in second position with 2,700 ha area for this pattern, however, this upazila has allotted the biggest share $(17.31 \%)$ of its NCA.
Fifth dominant cropping pattern

Fifth dominant cropping pattern MustardBoro-T. Aman had been covering 22,600 hectares representing $3.07 \%$ share of NCA in Jessore region (Table 14). This pattern is distributed over 21 upazilas where Magura sadar ranked in top position. This upazila had 3,500 ha area for Mustard-Boro-T. Aman pattern which is only $12.50 \%$ of upazila NCA and $15.49 \%$ of total Mustard-Boro-T. Aman area in the region.

Crop diversity and cropping intensity Higher number of available crops under cultivation in an area dictates its higher 
Table 11. Distribution of the $2^{\text {nd }}$ dominant Boro-Fallow-Fallow cropping pattern in Jessore region, $2014-15$.

\begin{tabular}{|c|c|c|c|c|}
\hline & Upazila & Area (ha) & $\%$ of upazila NCA & $\%$ of the pattern in region \\
\hline 01 & Abhaynagar & 7800 & 49.68 & 19.99 \\
\hline 02 & Keshabpur & 6000 & 31.50 & 15.38 \\
\hline 03 & Narail sadar & 5000 & 18.12 & 12.82 \\
\hline 04 & Shailkupa & 3000 & 10.68 & 7.69 \\
\hline 05 & Manirampur & 2500 & 7.02 & 6.41 \\
\hline 06 & Alamdanga & 2200 & 10.90 & 5.64 \\
\hline 07 & Moheshpur & 1960 & 6.03 & 5.02 \\
\hline 08 & Mohammadpur & 1500 & 9.62 & 3.85 \\
\hline 09 & Chougachha & 1300 & 7.43 & 3.33 \\
\hline 10 & Lohagara & 1200 & 5.53 & 3.08 \\
\hline 11 & Mirpur & 1100 & 4.80 & 2.82 \\
\hline 12 & Kotchandpur & 850 & 7.39 & 2.18 \\
\hline 13 & Sarsha & 700 & 2.73 & 1.79 \\
\hline 14 & Bagherpara & 650 & 3.49 & 1.67 \\
\hline 15 & Mujibnagar & 600 & 7.36 & 1.54 \\
\hline 16 & Kumarkhali & 600 & 3.66 & 1.54 \\
\hline 17 & Kaliganj & 400 & 2.00 & 1.29 \\
\hline 18 & Jhenaidaha sadar & 350 & 1.39 & 1.13 \\
\hline 19 & Magura sadar & 300 & 1.07 & 0.97 \\
\hline 20 & Bheramara & 300 & 4.05 & 0.97 \\
\hline 21 & Daulatpur & 250 & 0.76 & 0.81 \\
\hline 22 & Kushtia sadar & 200 & 0.94 & 0.65 \\
\hline 23 & Sreepur & 170 & 1.28 & 0.55 \\
\hline 24 & Jessore sadar & 80 & 0.26 & 0.26 \\
\hline & Jessore region & 39010 & 5.29 & 100.00 \\
\hline
\end{tabular}

diversity. Number of cropping patterns is also a gross indicator of crop diversity. A total of 176 cropping patterns were identified in the whole area of Jessore region under this investigation. The highest number of cropping patterns was identified 58 in Kushtia sadar, Mirpur and Kumarkhali upazilas; and that was 57 in Jessore sadar; and 46 in Daulatpur (Table 15). The lowest number of cropping patterns was identified 11 in Damurhuda followed by 12 in Jibannagar of Chuadanga district. The higher number of cropping patterns is generally related to higher level of diversity indices for cropping pattern. The lowest diversity index for cropping pattern was recorded 0.649 in Jhenaidaha sadar followed by 0.661 in Narail sadar. Lower diversity index for crops and cropping patterns is associated with water stagnation. In a study Shahidullah et al. (2006) found the lowest values for all the diversity and intensity parameters in salt affected area of greater Noakhali. The highest value of diversity index for cropping pattern was found 0.954 in Daulatpur upazila that was followed by 0.938 in Bheramara upazila. The lowest CDI was reported 0.852 in Narail sadar followed by 0.863 in Jessore sadar. The highest value of CDI was observed 0.981 in Daulatpur followed by 0.978 in Bheramara upazila. The range of cropping intensity values was recorded 168$271 \%$. The maximum value was for Sreepur of Magura district and minimum for Abhaynagar of Jessore district. As a whole the CDI of Jessore region was calculated 0.955 and the average cropping intensity at regional level was $229 \%$. In a simultaneous study, the investigators identified 316 cropping patterns for whole Bangladesh; where the CDI value was 0.952 at national level and the national average of cropping intensity was 200\% (Nasim et al, 2017). Diversification of crops helps risk reduction as diversification allows a producer to balance low price in one or two crops with reasonable prices 
Table 12. Distribution of the $3^{\text {rd }}$ dominant Wheat-Jute-T. Aman cropping pattern in Jessore region, 2014-15.

\begin{tabular}{|c|c|c|c|c|}
\hline & Upazila & Area (ha) & $\%$ of upazila NCA & $\%$ of the pattern in region \\
\hline 01 & Shailkupa & 3500 & 12.46 & 11.55 \\
\hline 02 & Meherpur sadar & 3000 & 14.71 & 9.90 \\
\hline 03 & Sreepur & 2800 & 21.05 & 9.24 \\
\hline 04 & Alamdanga & 2700 & 13.40 & 8.91 \\
\hline 05 & Mohammadpur & 1900 & 12.18 & 6.27 \\
\hline 06 & Daulatpur & 1700 & 5.17 & 5.61 \\
\hline 07 & Gangni & 1600 & 6.90 & 5.28 \\
\hline 08 & Kalia & 1500 & 6.52 & 4.95 \\
\hline 09 & Khoksa & 1300 & 19.40 & 4.29 \\
\hline 10 & Bheramara & 1200 & 16.22 & 3.96 \\
\hline 11 & Lohagara & 1150 & 5.30 & 3.80 \\
\hline 12 & Magura sadar & 1100 & 3.93 & 3.63 \\
\hline 13 & Mirpur & 860 & 3.76 & 2.84 \\
\hline 14 & Harinakundu & 650 & 5.24 & 2.15 \\
\hline 15 & Mujibnagar & 600 & 7.36 & 1.98 \\
\hline 16 & Kushtia sadar & 580 & 2.74 & 1.91 \\
\hline 17 & Kumarkhali & 500 & 3.05 & 1.65 \\
\hline 18 & Damurhuda & 500 & 2.24 & 1.65 \\
\hline 19 & Sarsha & 500 & 1.95 & 1.65 \\
\hline 20 & Manirampur & 500 & 1.40 & 1.65 \\
\hline 21 & Jibannagar & 400 & 2.65 & 1.32 \\
\hline 22 & Jhenaidaha sadar & 350 & 1.39 & 1.16 \\
\hline 23 & Shalikha & 350 & 2.03 & 1.16 \\
\hline 24 & Keshabpur & 320 & 1.68 & 1.06 \\
\hline 25 & Bagherpara & 200 & 1.08 & 0.66 \\
\hline 26 & Moheshpur & 200 & 0.62 & 0.66 \\
\hline 27 & Chougachha & 140 & 0.80 & 0.46 \\
\hline 28 & Jhikargachha & 100 & 0.43 & 0.33 \\
\hline \multirow[t]{2}{*}{29} & Kotchandpur & 100 & 0.87 & 0.33 \\
\hline & Jessore region & 30300 & 4.11 & 100.00 \\
\hline
\end{tabular}

in other (Blade and Slinkard, 2002). The farmers of Kerala diversified their cropping pattern to minimize risk from due to crop failures and price fluctuations (Mahesh, 1999).

\section{COCLUSION}

The cropping intensity of the Jessore region was higher than the national average. BoroFallow-T. Aman, Single Boro, Wheat-Jute-T. Aman, Lentil-Jute-T. Aman and MustardBoro-T. Aman were the dominant cropping patterns in the region. Exclusive rice area is about four folds of exclusive non-rice area. In Jessore region crop diversity is much wider than that of other regions. Based on the findings of the study, the following recommendations were made.

- Initiative to be taken to increase productivity of exclusive rice based cropping pattern. The high yielding varieties of rice along with recommended crop management packages to be adopted.

- Effort might be invested so that a portion of double-rice area could be brought under Potato-Boro-T. Aman and/or other alternative three cropping systems. 
Table 13. Distribution of the $4^{\text {th }}$ dominant Lentil-Jute-T. Aman cropping pattern in Jessore region, $2014-15$.

\begin{tabular}{|c|c|c|c|c|}
\hline & Upazila & Area (ha) & $\%$ of upazila NCA & $\%$ of the pattern in region \\
\hline 01 & Magura sadar & 4400 & 15.71 & 14.84 \\
\hline 02 & Mohammadpur & 2700 & 17.31 & 9.11 \\
\hline 03 & Shalikha & 2400 & 13.91 & 8.09 \\
\hline 04 & Sreepur & 2300 & 17.29 & 7.76 \\
\hline 05 & Lohagara & 2200 & 10.14 & 7.42 \\
\hline 06 & Manirampur & 2200 & 6.18 & 7.42 \\
\hline 07 & Bagherpara & 1980 & 10.65 & 6.68 \\
\hline 08 & Kaliganj & 1600 & 8.00 & 5.40 \\
\hline 09 & Jhenaidaha sadar & 1600 & 6.35 & 5.40 \\
\hline 10 & Jhikargachha & 1300 & 5.59 & 4.38 \\
\hline 11 & Gangni & 1200 & 5.17 & 4.05 \\
\hline 12 & Kumarkhali & 1000 & 6.10 & 3.37 \\
\hline 13 & Sarsha & 800 & 3.13 & 2.70 \\
\hline 14 & Mirpur & 750 & 3.28 & 2.53 \\
\hline 15 & Khoksa & 700 & 10.45 & 2.36 \\
\hline 16 & Bheramara & 600 & 8.11 & 2.02 \\
\hline 17 & Chougachha & 600 & 3.43 & 2.02 \\
\hline 18 & Keshabpur & 550 & 2.89 & 1.85 \\
\hline 19 & Narail sadar & 350 & 1.27 & 1.18 \\
\hline 20 & Jessore sadar & 200 & 0.65 & 0.67 \\
\hline 21 & Alamdanga & 100 & 0.36 & 0.34 \\
\hline 22 & Mujibnagar & 80 & 0.98 & 0.27 \\
\hline \multirow[t]{2}{*}{23} & Chuadanga sadar & 40 & 0.21 & 0.13 \\
\hline & Jessore region & 29650 & 4.02 & 100.00 \\
\hline
\end{tabular}

Table 14. Distribution of the $5^{\text {th }}$ dominant Mustard-Boro-T. Aman cropping pattern in Jessore region, $2014-15$.

\begin{tabular}{|c|c|c|c|c|}
\hline & Upazila & Area (ha) & $\%$ of upazila NCA & $\%$ of the pattern in region \\
\hline 01 & Magura sadar & 3500 & 12.50 & 15.49 \\
\hline 02 & Jhenaidaha sadar & 2400 & 9.52 & 10.62 \\
\hline 03 & Jessore sadar & 2200 & 7.18 & 9.73 \\
\hline 04 & Moheshpur & 2150 & 6.62 & 9.51 \\
\hline 05 & Bagherpara & 1700 & 9.14 & 7.52 \\
\hline 06 & Shalikha & 1600 & 9.28 & 7.08 \\
\hline 07 & Chougachha & 1300 & 7.43 & 5.75 \\
\hline 08 & Kaliganj & 1000 & 5.00 & 4.42 \\
\hline 09 & Meherpur sadar & 1000 & 4.90 & 4.42 \\
\hline 10 & Gangni & 1000 & 4.31 & 4.42 \\
\hline 11 & Narail sadar & 950 & 3.44 & 4.20 \\
\hline 12 & Shailkupa & 600 & 2.14 & 2.65 \\
\hline 13 & Kotchandpur & 500 & 4.35 & 2.21 \\
\hline 14 & Kushtia sadar & 450 & 2.12 & 1.77 \\
\hline 15 & Alamdanga & 400 & 1.42 & 1.77 \\
\hline 16 & Abhaynagar & 400 & 2.55 & 1.77 \\
\hline 17 & Jhikargachha & 400 & 1.72 & 1.77 \\
\hline 18 & Harinakundu & 400 & 3.23 & 1.77 \\
\hline 19 & Mujibnagar & 400 & 4.91 & 1.77 \\
\hline 20 & Khoksa & 200 & 2.99 & 0.88 \\
\hline & Kumarkhali & 50 & 0.30 & 0.22 \\
\hline & Jessore region & 22600 & 3.07 & 100.00 \\
\hline
\end{tabular}


Table 15. Crop diversity and cropping intensity in Jessore region, 2014-15.

\begin{tabular}{|c|c|c|c|c|c|c|}
\hline & Upazila & $\begin{array}{l}\text { No. of identified } \\
\text { pattern }\end{array}$ & $\begin{array}{l}\text { No. of } \\
\text { crop }\end{array}$ & $\begin{array}{l}\text { Diversity index for } \\
\text { cropping pattern }\end{array}$ & $\begin{array}{l}\text { Crop diversity } \\
\text { index (CDI) }\end{array}$ & C.I. (\%) \\
\hline 01 & Jessore sadar & 57 & 16 & 0.679 & 0.863 & 233 \\
\hline 02 & Keshabpur & 22 & 18 & 0.800 & 0.921 & 188 \\
\hline 03 & Manirampur & 24 & 14 & 0.792 & 0.923 & 242 \\
\hline 04 & Abhaynagar & 20 & 16 & 0.685 & 0.871 & 168 \\
\hline 05 & Jhikargachha & 30 & 20 & 0.797 & 0.925 & 235 \\
\hline 06 & Sarsha & 19 & 18 & 0.723 & 0.903 & 241 \\
\hline 07 & Bagherpara & 27 & 22 & 0.695 & 0.889 & 235 \\
\hline 08 & Chougachha & 22 & 18 & 0.747 & 0.903 & 223 \\
\hline 09 & Kushtia sadar & 58 & 18 & 0.818 & 0.946 & 232 \\
\hline 10 & Mirpur & 58 & 24 & 0.900 & 0.963 & 264 \\
\hline 11 & Kumarkhali & 58 & 23 & 0.928 & 0.973 & 231 \\
\hline 12 & Khoksa & 20 & 20 & 0.887 & 0.970 & 240 \\
\hline 13 & Daulatpur & 46 & 23 & 0.954 & 0.981 & 236 \\
\hline 14 & Bheramara & 29 & 19 & 0.938 & 0.978 & 226 \\
\hline 15 & Magura sadar & 33 & 23 & 0.830 & 0.939 & 250 \\
\hline 16 & Sreepur & 17 & 16 & 0.858 & 0.948 & 271 \\
\hline 17 & Shalikha & 22 & 16 & 0.749 & 0.911 & 246 \\
\hline 18 & Mohammadpur & 30 & 18 & 0.906 & 0.960 & 241 \\
\hline 19 & Meherpur sadar & 23 & 17 & 0.892 & 0.961 & 241 \\
\hline 20 & Gangni & 25 & 14 & 0.925 & 0.972 & 244 \\
\hline 21 & Mujibnagar & 19 & 13 & 0.902 & 0.962 & 218 \\
\hline 22 & Narail sadar & 15 & 14 & 0.661 & 0.852 & 198 \\
\hline 23 & Lohagara & 19 & 16 & 0.906 & 0.959 & 224 \\
\hline 24 & Kalia & 22 & 13 & 0.830 & 0.924 & 209 \\
\hline 25 & Jhenaidaha sadar & 19 & 17 & 0.649 & 0.876 & 227 \\
\hline 26 & Shailkupa & 14 & 16 & 0.842 & 0.947 & 239 \\
\hline 27 & Kotchandpur & 22 & 12 & 0.794 & 0.917 & 205 \\
\hline 28 & Moheshpur & 33 & 22 & 0.857 & 0.942 & 217 \\
\hline 29 & Harinakundu & 25 & 17 & 0.710 & 0.903 & 207 \\
\hline 30 & Kaliganj & 26 & 18 & 0.712 & 0.902 & 227 \\
\hline 31 & Chuadnga sadar & 22 & 19 & 0.849 & 0.938 & 216 \\
\hline 32 & Alamdanga & 24 & 18 & 0.855 & 0.939 & 208 \\
\hline 33 & Jibannagar & 12 & 14 & 0.767 & 0.922 & 255 \\
\hline \multirow[t]{2}{*}{34} & Damurhuda & 11 & 13 & 0.775 & 0.914 & 232 \\
\hline & Jessore region & 176 & 35 & 0.884 & 0.955 & 229 \\
\hline
\end{tabular}

- In the single Boro area suitable vegetables might be grown on floating bed system in wet season.

- The upazilas having unique or exceptional cropping patterns with large area coverage might be studied in-depth to extrapolate to similar environments.

\section{REFERENCES}

Agrawal, D J and A H Kassam. 1976. The importance of multiple cropping in increasing world food supplies. A special publication No. 27, American Society of Agronomy, Madison, Wisconsin. pp. 2-3.

Blade, S F and A E Slinkard 2002. New Crop Development: The Canadian Experience. In: Trends in New Crops 
and New Uses. J Janick and A Whipkey (Editors). ASHS Press, Alexandria.

FAO, 1988. Land Resources Appraisal of Bangladesh for Agricultural Development- Report 2: Agroecological regions of Bangladesh. Food and Agriculture Organization of the United Nations, Rome, Italy, 570p.

Gadge, S S. 2003. Influence of changes in cropping pattern on farmers' economic status. Indian J. Ext. Edu. 39(1\&2): 99-101.

Kshirsagar, K G, S Pandey and M R Bellon. 1997. Farmers' perception, varietal characteristics and technology adoption: the case of rainfed village in eastern India. Discussion paper 5/97. Social Sciences Division, International Rice Research Institute. Los Baňos, Laguna, Philippines.

Mahesh, R. 1999. Causes and consequences of change in cropping pattern: A location specific study. Discussion Paper No. 11, Kerala Research Programme on Local Level Development, Centre for Development Studies, Thiruvananthapura.

Mandal, R and M P Bezbaruah. 2013. Diversification of cropping pattern: its determinants and role in flood affected agriculture of Assam Plains. Indian J. Agric. Econ. 68(2): 169-181.

Muttaleb, M A, S M Shahidullah, M Nasim and A Saha. 2017. Cropping systems and land uuse in Sylhet region. Bangladesh Rice J. 21(2): 273-288.

Nasim, M, S M Shahidullah, A Saha, M A Muttaleb, T L Aditya, M A Ali and M S Kabir. 2017. Distribution of Crops and Cropping Patterns in Bangladesh. Bangladesh Rice J. 21(2): 1-55.

Neena, D. 1998. Interstate variation in cropping pattern in India. Indian J. Regi. Sci. 30(2): 57-69.

Shahidullah, S M, M S A Talukder, M S Kabir, A H Khan and N E Elahi. 2006. Cropping patterns in the South East Coastal Region of Bangladesh. J. Agric. Rural Dev. 4(1\&2): 53-60.

Shahidullah, S M, M Nasim, M K Quais and A Saha. 2017. Diversity of Cropping Systems in Chittagong Region. Bangladesh Rice J. 21(2): 109-122.

Shriar, A J. 2000. Agricultural intensity and its measurement in frontier regions. Agroforestry Systems. 49(3): 301-318.

Appendix 1. List of cropping patterns in Jessore region, 2014-15.

\begin{tabular}{|c|c|c|c|c|c|}
\hline & Cropping pattern & Area (ha) & & Cropping pattern & Area (ha) \\
\hline 001 & Boro-Fallow-T. Aman & 237850 & 069 & Wheat-Vegetab-Vegetab & 1240 \\
\hline 002 & Boro-Fallow-Fallow & 39010 & 070 & Mustard-Boro-Jute & 1200 \\
\hline 003 & Wheat-Jute-T. Aman & 30300 & 071 & Pea-Jute-Fallow & 1170 \\
\hline 004 & Lentil-Jute-T. Aman & 29650 & 072 & Potato-Jute-T. Aman & 1150 \\
\hline 005 & Mustard-Boro-T. Aman & 22600 & 073 & Potato-Vegetab-T. Aman & 1120 \\
\hline 006 & Boro-Aus-T. Aman & 20350 & 074 & Grasspea-Fallow-T. Aman & 1100 \\
\hline 007 & Vegetab-Vegetab-Vegetab & 19170 & 075 & Wheat-Jute-Vegetab & 1100 \\
\hline 008 & Boro-Aus-Fallow & 17000 & 076 & Onion-Aus-T. Aman & 1060 \\
\hline 009 & Tobacco-Jute-T. Aman & 12180 & 077 & Garlic-Jute-Fallow & 1040 \\
\hline 010 & Maize-Aus-Fallow & 10850 & 078 & Coriander-Jute-T. Aman & 1010 \\
\hline 011 & Onion-Jute-T. Aman & 10740 & 079 & Onion-Aus-Fallow & 1000 \\
\hline 012 & Mustard-Jute-T. Aman & 10710 & 080 & Potato-Mungbean-T. Aman & 930 \\
\hline 013 & Maize-Jute-Fallow & 9900 & 081 & Tobacco-Aus-Fallow & 930 \\
\hline 014 & Maize-Fallow-T. Aman & 9000 & 082 & Grasspea-Aus-T. Aman & 900 \\
\hline 015 & Boro-B.Aman & 8250 & 083 & Mustard-Maize-T. Aman & 900 \\
\hline 016 & Wheat-Jute-Fallow & 7960 & 084 & Pea-Aus-Vegetab & 900 \\
\hline 017 & Lentil-Jute-Fallow & 7550 & 085 & Vegetab-Maize-T. Aman & 880 \\
\hline 018 & Boro-Sesbania-T. Aman & 6850 & 086 & Garlic-Vegetab-Vegetab & 850 \\
\hline 019 & Lentil-Sesame-T. Aman & 6630 & 087 & Chilli-Fallow-Fallow & 840 \\
\hline 020 & Boro-Jute-T. Aman & 6320 & 088 & Wheat-Mungbean-T. Aman & 810 \\
\hline 021 & Boro-Jute-Fallow & 6250 & 089 & Maize-Mungbean-Vegetab & 800 \\
\hline 022 & Grasspea-Jute-Fallow & 6140 & 090 & Pea-Vegetab-Fallow & 800 \\
\hline 023 & Maize-Jute-T. Aman & 5580 & 091 & Vegetab-Jute-Vegetab & 800 \\
\hline 024 & Lentil-Mungbean-T. Aman & 5080 & 092 & Lentil-Sesame-Fallow & 770 \\
\hline 025 & Mustard-Boro-Aus & 5050 & 093 & Chilli-Jute-T. Aman & 740 \\
\hline 026 & Maize-Mungbean-T. Aman & 4900 & 094 & Pea-Fallow-T. Aman & 740 \\
\hline
\end{tabular}


Appendix 1. Continued.

\begin{tabular}{|c|c|c|c|c|c|}
\hline & Cropping pattern & Area (ha) & & Cropping pattern & Area (ha) \\
\hline 027 & Lentil-Aus-T. Aman & 4800 & 095 & Wheat-Vegetab-T. Aman & 670 \\
\hline 028 & Grasspea-B.Aman & 4450 & 096 & Onion-Sesame-T. Aman & 650 \\
\hline 029 & Vegetab-Vegetab-T. Aman & 4360 & 097 & Cotton-Aus-Fallow & 630 \\
\hline 030 & Vegetab-Vegetab-Fallow & 4120 & 098 & Maize-Groundnut & 620 \\
\hline 031 & Tobacco-Jute-Fallow & 3950 & 099 & Potato-Sesame-T. Aman & 620 \\
\hline 032 & Wheat-Sesame-T. Aman & 3750 & 100 & Vegetab-Boro-T. Aman & 600 \\
\hline 033 & Wheat-Chilli-Fallow & 3350 & 101 & Wheat-Aus-Cotton & 600 \\
\hline 034 & Garlic-Jute-T. Aman & 3100 & 102 & Maize-Aus-T. Aman & 580 \\
\hline 035 & Maize-Aus-Vegetab & 3000 & 103 & Chilli-Fallow-T. Aman & 570 \\
\hline 036 & Lentil-Aus-Fallow & 2950 & 104 & Potato-Maize-T. Aman & 550 \\
\hline 037 & Tobacco-Aus-T. Aman & 2950 & 105 & Potato-Sesame-Fallow & 540 \\
\hline 038 & Wheat-Fallow-T. Aman & 2910 & 106 & Boro-Fallow-Blackgram & 530 \\
\hline 039 & Boro-Vegetab(Float/Norm) & 2850 & 107 & Potato-Jute-Fallow & 530 \\
\hline 040 & Lentil-Vegetab-Vegetab & 2780 & 108 & Vegetab-Maize-Fallow & 510 \\
\hline 041 & Wheat-Jute-Blackgram & 2750 & 109 & Fallow-B.Aus+B.Aman & 500 \\
\hline 042 & Onion-Jute-Fallow & 2600 & 110 & Groundnut- Aus-T. Aman & 500 \\
\hline 043 & Mustard-Boro-Jute-T. Aman & 2500 & 111 & Potato-S.gourd-Aus & 500 \\
\hline 044 & Mustard-Mungbean-T. Aman & 2370 & 112 & Vegetab-Fallow-T. Aman & 500 \\
\hline 045 & Lentil-Vegetab-T. Aman & 2250 & 113 & Mustard-Jute-Fallow & 450 \\
\hline 046 & Mustard-Aus-T. Aman & 2220 & 114 & Boro-Chilli-Fallow & 350 \\
\hline 047 & Grasspea-Jute-T. Aman & 2150 & 115 & Coriander-Fallow-Fallow & 300 \\
\hline 048 & Wheat-Aus-T. Aman & 2130 & 116 & Blackgram-Jute-T. Aman & 300 \\
\hline 049 & Onion-Vegtab-Vegetab & 2090 & 117 & 03.Fallow-Fallow-T. Aman & 300 \\
\hline 050 & Mustard-Sesame-T. Aman & 2060 & 118 & Mungbean-Aus-T. Aman & 300 \\
\hline 051 & Wheat-Aus-Fallow & 1910 & 119 & Mustard-Fallow-T. Aman & 300 \\
\hline 052 & Mustard-Jute-Vegetab & 1900 & 120 & Potato-Boro-Vegetab & 300 \\
\hline 053 & Maize-Vegetab-Fallow & 1750 & 121 & Wheat-Aus-Blackgram & 300 \\
\hline 054 & Onion-Fallow-T. Aman & 1750 & 122 & Pea-B.Aman & 280 \\
\hline 055 & Vegetab-Jute-Fallow & 1730 & 123 & Maize-Sesame-Fallow & 280 \\
\hline 056 & Tobacco-Fallow-T. Aman & 1670 & 124 & Chilli-Aus-T. Aman & 270 \\
\hline 057 & Mustard-Boro-Aus-T. Aman & 1650 & 125 & Potato-Boro-Jute & 250 \\
\hline 058 & Boro-Vegetab-T. Aman & 1620 & 126 & Lentil-Fallow-T. Aman & 240 \\
\hline 059 & Tobacco-Sesbania-T. Aman & 1620 & 127 & Garlic-B.Aman & 210 \\
\hline 060 & Vegetab-Aus-Fallow & 1600 & 128 & Mustard-Aus-Fallow & 200 \\
\hline 061 & Vegetab-Boro-Fallow & 1550 & 129 & Chilli-Aus-Fallow & 200 \\
\hline 062 & Maize-Sesame-T. Aman & 1530 & 130 & Coriander-Jute-Fallow & 200 \\
\hline 063 & Vegetab-Aus-T. Aman & 1400 & 131 & Grasspea-B.Aus+B.Aman & 200 \\
\hline 064 & Chilli-Vegetab-Fallow & 1330 & 132 & Grasspea-Sesame-Fallow & 200 \\
\hline 065 & Vegetab-Jute-T. Aman & 1310 & 133 & Mustard-Maize-Jute & 200 \\
\hline 066 & Mustard-Boro-Fallow & 1290 & 134 & Onion-Aus-Blackgram & 200 \\
\hline 067 & Maize-Vegetab-T. Aman & 1260 & 135 & Potato-Boro-Aus & 200 \\
\hline \multirow[t]{2}{*}{068} & Vegetab-Fallow-Blackgram & 1250 & 136 & Potato-Boro-Jute-T. Aman & 200 \\
\hline & & & $137-176$ & Other 40 patterns (Table 9) & 3890 \\
\hline
\end{tabular}

